\title{
Efficiency of application of biofertilizers at seed treatment of soft winter wheat
}

Dubovyk D.

The V.M. Remeslo Myronivka Institute of Wheat NAAS of Ukraine

\author{
* - Supervisor - doctor of agricultural sciences, professor, corresponding member of NAAS \\ S.M. Kalenska
}

The purpose. To determine effect of application of biofertilizers at seed treatment of soft wheat upon productivity of grain, sowing qualities of seeds and economic efficiency. Methods. Field, laboratory, mathematical. Results. It is shown that at treatment of seeds with disinfectant and biofertilizers the cost price of cash grain drops for $7-22 \mathrm{hrn} / \mathrm{c}$, profit level increases for $1064-2038 \mathrm{hrn} / \mathrm{hectare}$, and profitableness - for $5-16 \%$ in comparison with control. Conclusions. They fixed efficiency of use of biofertilizers Biocomplex BTU and Riverm at treatment of seeds in techniques of growing of soft winter wheat. That promotes augmentation of productivity, martempering of sowing qualities of seeds and increase of economic efficiency as a whole and net profit in particular.

Key words: soft winter wheat, disinfectant, biofertilizer, productivity, sowing qualities of seeds, economic efficiency.

Introduction. The production of high quality grain is becoming a more acute problem in crop production. The development of regionally adapted resource-saving technologies for the cultivation of new winter wheat varieties with the use of modern biological means for specific soil-climatic zones and microzone will enable the implementation of genetic abilities of breeding novelties.

Analysis of research and publications, problem statement. Growth regulators of new-generation plants have good fungicidal properties, so it is advisable to make them in combination with the trachea, which greatly enhances the effect of the latter on pathogens. It is possible to share them both for presowing seed treatment and for spraying crops, as demonstrated in experiments with winter wheat, barley fescue and other crops. The use of plant growth regulators with pesticides makes it possible to reduce the dose of the latter (by 25-30\%) without reducing their protective effect [1-3].

The generalization of the results of 530 experiments in different soil-climatic zones of Ukraine showed that in 46 experiments with wheat, winter growth of bio-fertilizer yields reached 6-9\%, confirming data on the technological role of biologically active substances as a reserve for increasing the yield and quality of crops [4].

The efficiency of using biofertilizers on seed crops of Mironovsky VM wheat institute was proved. NAAS handicrafts, which contributed to an increase in the mass of 1000 seeds and improved crop seed quality [5].

Consequently, the problem of protection of seeds and winter wheat seedlings is relevant, which has led us to carry out special laboratory and field studies on the effectiveness of sowing seed treatment with various biofuels in conjunction with a fertilizer.

The purpose and task of the research - to determine the effect of the use of bio fertilizers on the maturation of seeds of soft winter wheat varieties on grain yield and economic efficiency.

Materials and methods of research. The research was carried out in field experiments of the Seedling Department of Mironovsky VM Wheat Institute. NAAS Handicrafts during 2012-2014, located in the south-eastern part of the Kiev region on the watershed of the Ros and Rosava rivers, in the Rightbank Forest-steppe of Ukraine. The soils are represented by black earths, medium, and strongly leached. 
The capacity of the humus horizon is $38-40 \mathrm{~cm}$. The carbonate layer lies at a depth of $45-65 \mathrm{~cm}$. The soilforming rock is a pale carbonate forest of light-loam mechanical composition. Ground water lies at a depth of $50-60 \mathrm{~m}$ and does not affect the soil-forming process. The content of humus is $3.6-4.5 \%$, hydrolyzed nitrogen - 5.5-6.4 mg, mobile phosphorus - 19.0-27.1 mg and exchangeable potassium - 11.2$18.0 \mathrm{mg}$ per $100 \mathrm{~g}$ soil, $\mathrm{pH}$ of salt - 5,3-6,4, the amount of absorbed bases - 23,1-28,6 mg-eq. per $100 \mathrm{~g}$ soil, the degree of saturation with the basics $-86.2-94.4 \%$. Such soils have a high and medium supply of mineral nutrients and are characterized by weak acid, close to the neutral, reaction of soil solution, which has a good effect on the productivity of winter wheat.

In particular, the characteristic feature of the climate of Kyiv region and Myronivsky district is its moderate continent, which is manifested in the relatively gradual change of winter in the spring and then in summer and in moderate amounts of precipitation [6].

The hydrothermal regime during the years of research was contrasting and varied over the years, which makes it possible to more objectively estimate the effect of bio fertilizers on seed fertilization on yield and crop quality of winter wheat.

Field experiments were carried out in accordance with the method of state variety testing [7] at sites of $10 \mathrm{~m} 2$ in a six-time repetition. Agrotechnics in experiments are generally accepted for the conditions of the Right Bank Forest-steppe of Ukraine. Seed of wheat varieties of winter wheat, Kolos Mironivshchyna, Mironovskaya century, Natalka and Yuvylir Mironivsky, carried out a sowing machine of $\mathrm{CH}-10 \mathrm{C}$ on a predecessor sederal couples with a seed rate of 5 million similar seeds per 1 hectare. Seeds were treated with bio-fertilizers (Biocomplex BTU $0.8 \mathrm{I} / \mathrm{t}$ and Riverm $0.3 \mathrm{I} / \mathrm{ton}$ ), the drug (fungicidal action of Yunt Kvadro (clothianidin $166.7 \mathrm{~g} / \mathrm{I}+$ imidacloprid $166.7 \mathrm{~g} / \mathrm{I}+$ protiokonazole $33.3 \mathrm{~g} / \mathrm{I}+$ tebuconazole $6.7 \mathrm{~g} /$ I) $-1.5 \mathrm{I} / \mathrm{t}$ ) according to the experimental scheme. Harvesting was carried out by continuous threshing of the accounting station by the Sampo-130 combine, with the subsequent transfer to standard (14\%) moisture content of the grain.

Mathematical processing of experimental data was carried out by the method of dispersion analysis [89]. The calculations of economic efficiency are carried out in accordance with the generally accepted method [10] at 2015 prices. The calculations were performed in the Statistica and Excel programs.

Research results and their discussion. The processing of winter wheat varieties of wheat strawberries Riverm ( $0.3 \mathrm{l} / \mathrm{t}$ ) and Biocomplex BTU (0.8I/ ton) increased yields by an average of 0.43-

0.56 tons per hectare per hectare, and in combination with a pretreatment Yunda Kvadro $(1,5 \mathrm{I} / \mathrm{t})$ - at $0,85-1,01 \mathrm{t} /$ hectare compared to the control (Table 1). The maximum yield was 5.96 tons per hectare over the years, on average in grades, was obtained on the variant of seed treatment by the Utunt Kvadro (1.5 I/ ton), + Biocomplex BTU $(0.8 \mathrm{~kg} / \mathrm{t})$, at the control -4.95 tons $/ \mathrm{Ha}$.

1. Yield of wheat grain of soft winter depending on the variant of seed treatment, $t /$ ha (MIP, average for 2012-2014).

\begin{tabular}{|l|l|l|l|l|}
\hline Version & $\mathbf{2 0 1 2}$ & $\mathbf{2 0 1 3}$ & $\mathbf{2 0 1 4}$ & Medium \\
\hline Control (no processing) & 4,84 & 3,60 & 6,42 & 4,95 \\
\hline Yunda Quadro, 1.5 I/ ton & 5,11 & 4,14 & 6,92 & 5,39 \\
\hline Biocomplex BTU, 0,8 I/ ton & 5,14 & 4,32 & 7,08 & 5,51 \\
\hline River, 0.3 I / ton & 5,12 & 4,16 & 6,86 & 5,38 \\
\hline Yunta quad, 1.5 I/ t + Biocomplex BTU, 0.8I/ ton & 5,35 & 4,74 & 7,81 & 5,96 \\
\hline Yunta quad, 1.5 I/ t + River, 0.3 I / ton & 5,29 & 4,61 & 7,52 & 5,80 \\
\hline NIR05 & 0,24 & 0,25 & 0,32 & 0,29 \\
\hline
\end{tabular}

Calculations show that the conditional profit for all variants of processing increased by 1064-2038 $\mathrm{UAH} /$ hectare compared to the control. The maximum profit on the average in grades - $7749 \mathrm{UAH} / \mathrm{ha}$ was received for the processing of seeds by biofuel Biocomplex BTU, which for $2038 \mathrm{UAH} /$ ha exceeded the control version (Table 2). 
2. Economic efficiency of growing of winter wheat depending on variants of seed treatment (MIP, average for 2012-2014).

\begin{tabular}{|c|c|c|c|c|c|c|c|}
\hline Version & $\begin{array}{l}\text { Yield, } \\
\text { t / ha }\end{array}$ & $\begin{array}{l}+/- \text { to } \\
\text { contro } \\
\text { I }\end{array}$ & $\begin{array}{l}\text { Total } \\
\text { costs } \\
\text { UAH / ha }\end{array}$ & $\begin{array}{l}\text { Cost of } \\
\text { gross } \\
\text { output, } \\
\text { UAH }\end{array}$ & $\begin{array}{l}\text { Cost of } 1 \\
\text { ts, UAH }\end{array}$ & $\begin{array}{l}\text { Profit } \\
\text { UAH / ha }\end{array}$ & $\begin{array}{l}\text { Profitabili } \\
\text { ty,\% }\end{array}$ \\
\hline Control (no processing) & 4,95 & - & 11785 & 17496 & 242,49 & 5711 & 48 \\
\hline Yunda Quadro, 1.5 I/ ton & 5,39 & $+0,44$ & 12881 & 19656 & 235,92 & 6775 & 53 \\
\hline Biocomplex BTU, 0,8 I/ ton & 5,51 & $+0,56$ & 12195 & 19944 & 220,13 & 7749 & 64 \\
\hline River, 0.3 I/ ton & 5,38 & $+0,43$ & 12145 & 19692 & 222,04 & 7547 & 62 \\
\hline $\begin{array}{l}\text { Yunta quad, } 1.5 \mathrm{I} / \mathrm{t}+\text { Biocomplex } \\
\text { BTU, } 0.8 \mathrm{I} / \text { ton }\end{array}$ & 5,96 & $+1,01$ & 13049 & 20556 & 228,52 & 7507 & 58 \\
\hline $\begin{array}{l}\text { Yunta quad, } 1.5 \mathrm{I} / \mathrm{t}+\text { River, } 0.3 \mathrm{I} / \\
\text { ton }\end{array}$ & 5,80 & $+0,85$ & 12989 & 20232 & 231,12 & 7243 & 56 \\
\hline
\end{tabular}

At all variants of seed treatment, the cost of 1 ts of grain decreased by UAH 7-22, the level of profitability increased by $5-16 \%$ compared with the control.

For processing seeds of biofertilizers on elite crops of wheat, the soft winter income will increase by 3600-5100 UAH / ha compared to the control.

Thus, in the conditions of the Right Bank Forest-steppe Ukraine, the processing of seeds by biofertilizers in a complex with the polluter on the level of profitability and net profit is a highly effective agrotechnical measure.

\section{Conclusion}

We installed bio Biocomplex efficiency and BTU Riverm for seed treatment technology in soft winter wheat, which increases productivity and increase economic efficiency in general and in particular the net profit.

\section{References}

1. Exact agriculture / [D. Shpar, A. Zakharenko, S. Kalenskaya, V. Yakushev]. - St. Petersburg Pushkin, 2009. - $397 \mathrm{p}$.

2. Kavunets V.P. Seedling of soft winter wheat / V.P.Kavunets, V.S. Kochmarsky. - Myronivka, 2011. $320 \mathrm{p}$.

3. Wilson B.J. Ammonium sulfate endorsement of picloram absorption by detached leaves / B.J. Wilson, R.K. Nishmoto // Weed Sci. 1975th Vol. 23. P. 297-301.

4. Fateev A.I. Fundamentals of Microfertilizers Application / AI Fateev, MA Zakharova - Kharkiv: KP "Typography, 2005. - $134 \mathrm{p}$.

5. Indigenous nutrition / VS Kochmarsky, V.P.Kavunets, A.Siroshtan, D.Yu. Dubovik [and others] // Seed production. - 2014. - No. 5. - S. 5-7.

6. Agroclimatic bulletin of multi-year data on the Mironovsky district of the Kiev region. - K.: UkrUGKS, 1985. - $215 \mathrm{p}$.

7. The method of state varietal testing of agricultural crops. - M.: Kolos, 1971 - Vip. 1/2. - 487 pp.

8. Armor B.A. Method of field experiment / B. A. A. Kospehov - M.: Agropromizdat, 1985. - $351 \mathrm{p}$.

9. Statistical processing of the results of agronomic research: [tutorial] / A.O. Rozhkov, SM Kalenska, LM Puzik [and others. ]; for ed. A. A. Rozhkova // A Case Study in Agronomy. - Kh.: Maidan, 2016. - 298 p.

10. Sitnik V.P. Recommendations on the improvement of economic relations in the network of UAAS / VP Sitnik, O. M. Shpichak, P. T. Sabluk and others. - K., 2002. - 163 p. 